\title{
The art of creating culinary innovations
}

Received (in revised form): 16th May, 2008

\section{Marc Stierand}

is a trained chef and has worked in different Michelin star restaurants in Germany. He is currently completing his $\mathrm{PhD}$ at Strathclyde Business School on culinary innovations of elite chefs. His research interests comprise the areas of creativity, innovation, knowledge and process management.

\section{Paul Lynch}

has research interests and publications focusing upon commercial home enterprises, business networks and networking, social firms, and qualitative research methods. He is currently a reader at Strathclyde Business School.

AвSTRACt The life worlds of innovating chefs are identified as important aspects towards a better understanding of culinary innovation. Hence, the concept of personal culinary innovation is proposed as a verifiable way to identify innovators in the field. Current studies, however, interchangeably use the term invention and innovation and fail to address central dimensions such as artistic aspiration, continuous and discontinuous conditions, learning and networking, adoption and diffusion as well as perceived newness and change. As a result, improving the dialogue between chefs and scholars is believed to be the key to better research in the field.

Tourism and Hospitality Research (2008) 8, 337-350. doi:10.1057/thr.2008.28; published online 13 October 2008

KEYWORDS innovation, culinary, chef, artist

\section{INTRODUCTION: BACKGROUND TO THE STUDY}

The aim of this conceptual paper is to contribute to the progress of the culinary research agenda by highlighting gaps in current studies on culinary innovation and by recommending a multidisciplinary approach to interpret the voices of elite chefs that are considered as important for the uncovering of the multidimensional realities of culinary innovation. In other words, this study argues that the complex meanings of culinary innovation are embedded in the life worlds (Lebenswelten) of elite chefs so that their everyday actions and interactions become fundamental building blocks to explore the phenomenon of culinary innovation. Only in their worlds, can people know themselves

\footnotetext{
Marc Stierand

Department of Hospitality and Tourism Management,

Strathclyde Business School, Curran Building,

94 Cathedral Street, Glasgow G4 OLG, UK

Tel: + 44 (0)7807 823 167;

Fax: + $44(0) 141552$ 2870;

E-mail: marc.stierand@strath.ac.uk
}

(cf. Husserl, 1970/1936; Merleau-Ponty, $1962 / 1945)$ and that is why future studies on culinary innovation should be informed by the shared understanding and Dasein of elite chefs in the broader world of gastronomic institutionalism (see Heidegger, 1962/1927). As a result, the perceptions, beliefs, explanations, and views of elite chefs who construct culinary innovations are important aspects to identify the consequences they face for their behaviours and for those with whom they interact when they innovate (cf. Berger and Luckmann, 1966).

This paper particularly focuses on culinary innovation with regards to elite chefs, who are defined by their culinary value, which is acknowledged by Michelin's Guide Rouge. This restaurant guide is described as the most authoritative and widely recognised benchmark for the ranking of chefs and is said to be neutral towards different philosophies of cooking (cf. Durand et al., 2007; Rao et al., 2005). Elite chefs are further interesting in the light 
of culinary innovation, because they are part of the cultural field of Haute Cuisine that, like no other style of cooking, ties food to an intellectual discourse and expands cooking to theoretical codes and categories of practices (Ferguson, 2004; Rao et al., 2005). This paper claims that this intellectual dimension is important to let the yet generally unknown concept of culinary innovation emerge beyond the limited views of current studies. Moreover, this discourse is vital in order to be able to discuss culinary ideas that might be controversial to the institutional conventions of the gastronomic world, but that might be important for the development of the culinary guild (cf. Ganter, 2004). The power of such creative freedom can be manifested, for example, in the social movement in that a number of elite chefs revolted against the institution of gastronomy and so created the grounds on which the Nouvelle Cuisine was able to emerge ( $\mathrm{R}$ ao et al., 2003). At this time, these elite chefs started to abandon a centuries-old symbolic language (cf. Escoffier, 1993) as well as systems, routines and artefacts that were created by institutional logics (Monin, 2005). This movement made it possible that new and innovative styles of cooking, such as Jacques Maximin's 'Conceptualism', Michel Bra's 'Naturalism', Joël Robuchon and Freddy Girardet's 'Perfectionism', or Pierre Gagnaire's 'Style of Absolute Freedom', could develop (cf. Ferran Adria in Weber-Lamberdière, 2007).

More recently, a culinary development surfaced that incorporates scientific aspects into cooking and changes the conservative image of chefs as humble craftsmen. The names Ferran Adrià, Heston Blumenthal, and Thomas Keller, for example, became synonyms for this new approach to cooking, but it is also they who criticise that their New Cooking has been largely misunderstood, both outside and inside the culinary world by overemphasising and sensationalising certain aspects while ignoring others. This misinterpretation found its climax in the fashionable term Molecular Gastronomy that derived from the name of an academic workshop on the exploration of food chemistry in classical dishes in 1992. According to Adria et al. (2006), however, 'that workshop did not influence [their] approach, and the term "molecular gastronomy" does not describe [their] cooking, or indeed any style of cooking'. This claim clearly shows that academia must understand the worlds of these chefs before making definitive statements. Certainly, one can be inclined to say that this new cooking might be a New Nouvelle Cuisine, but any valid interpretation should be grounded in data that emerged in the life worlds of these innovative chefs. This case shows that there is a problem that practitioners and scientists speak dissimilar languages. This is also confirmed by Chef Ferran Adrià, who states that he and his team did not start to cooperate with any academician before 2003 when they found in the scientist and gastronome Pierre Castell a person with whom they were able for the first time to build a dialogue (Weber-Lamberdière, 2007).

As a result, this study portrays elite chefs as innovating and artistic omnivores rather than culinary snobs (cf. Peterson and Kern, 1996) and further argues that the phenomenon of culinary innovation seems to entail dimensions of creativity based on the elite chef's artistic aspiration, of learning and networking as well as dimensions of adoption and diffusion that are influenced by the tradition of the broader gastronomic world (the authors refer to the concept of tradition by Polányi, 1962a) and interpersonal relationships (cf. Scott, 2001). The exploration of these dimensions is believed to help in painting a richer picture about the sociology of elite chefs and this paper encourages scholars not to ignore complex phenomena like passion, ideas, and fantasy but rather to listen what their own intuitive perception tells that could improve the understanding of the multiple realities of culinary innovation (cf. Mill, 2002; Schopenhauer, 1851). Better understanding of these fuzzy and complex parts of culinary creations can also improve the image of elite chefs in the public media that starts to develop flavours of a food porn for the entertainment of an audience that would never 
dare to do what they see (cf.Anthony Bourdain in Hofer and Kamolz, 2007).

Food is a classifier, but food that is not as distinguished and beautiful like a fillet and that is aesthetically removed from the rest of the animal is considered ugly and vulgar (the authors refer here to Bourdieu, 1984). This attitude, however, can also be translated to the practice of research on culinary innovation. It seems that researchers directly focus on the distinguished and the beautiful of culinary innovation without taking into consideration the ugly and the vulgar. In other words, these scholars map a generic 'continuous innovation process' (eg Harrington, 2004a; Ottenbacher and Harrington, 2007) and ignore fuzzy, respectively, ugly, dimensions of culinary innovation. Such approaches create a poor language with a terminology that just helps to streamline the strategic planning and production of culinary creations. Some scholars (eg Ottenbacher and Harrington, 2007) seem to investigate in a world without irrationality and chaos (cf. Karl Popper quoted in Goldberg, 1985) and therefore ignore dimensions such as discontinuous and chaotic conditions as well as the importance of the perception of newness of the culinary innovation and its implication on change. These dimensions are influenced among other factors by the unexpected, incongruities, new knowledge, or changes in perception (cf. Drucker, 2006).

In consequence, five dimensions emerged within the above discourse that are by no means defining the entirety of the culinary innovation phenomenon, but that seem to be important and relevant dimensions helping to progress the culinary research agenda and to explore the sociology of elite chefs (Figure 1). These dimensions will further inform around 20 unstructured interviews that are planned with elite chefs in Europe, who will expectantly provide valuable grounding to amend and improve these five dimensions (see Figure 1).

\section{CRITICAL REVIEW OF LITERATURE}

Before engaging with the aforementioned dimensions, it is necessary to provide a clear distinction between invention and innovation as this appeared to be a major issue of misinterpretation in the literature on culinary innovation. Harrington (2004a,b), for example, creates an epistemology that defines culinary innovation as a process of new product development:

'Culinary innovations are generally productoriented, but the innovation process also applies to innovations in service as both types lie somewhere on a service-product continuum. ...culinary innovations, culinary products and culinary product development are used interchangeably as all of these concepts reflect innovative food items consumed in a foodservice establishment'. (Harrington, 2004a)

In light of this narrowly defined view, Harrington limits the yet unknown concept of culinary innovation to emerge beyond the scope of goods and services. Rehn (2006), in contrast, provides a stimulating discourse on innovation as a manipulation of history and uses the example of Antonin Carême as a historic figure, who changed the conventional way of thinking about food and thus created a form of culinary innovation. Moreover, Rodgers (2008) discusses the technological aspects of innovation with regards to food production. New technologies are an important factor in the exploration of culinary innovation, because they can be both influenced by chefs and they can influence chefs in their practices and learning. Rehn and Rodgers challenge the conventional image of culinary innovation and inspire a reader to think broader and more thoroughly about any ad hoc conceptualisations.

Vahs and Burmester (2002), for example, illustrate under a management lens (Figure 2) the scope of innovation management in comparison to research and development (R\&D) and technology management that can help to resolve future terminological misinterpretations, even on a broader and multidisciplinary understanding of the innovation phenomenon. 


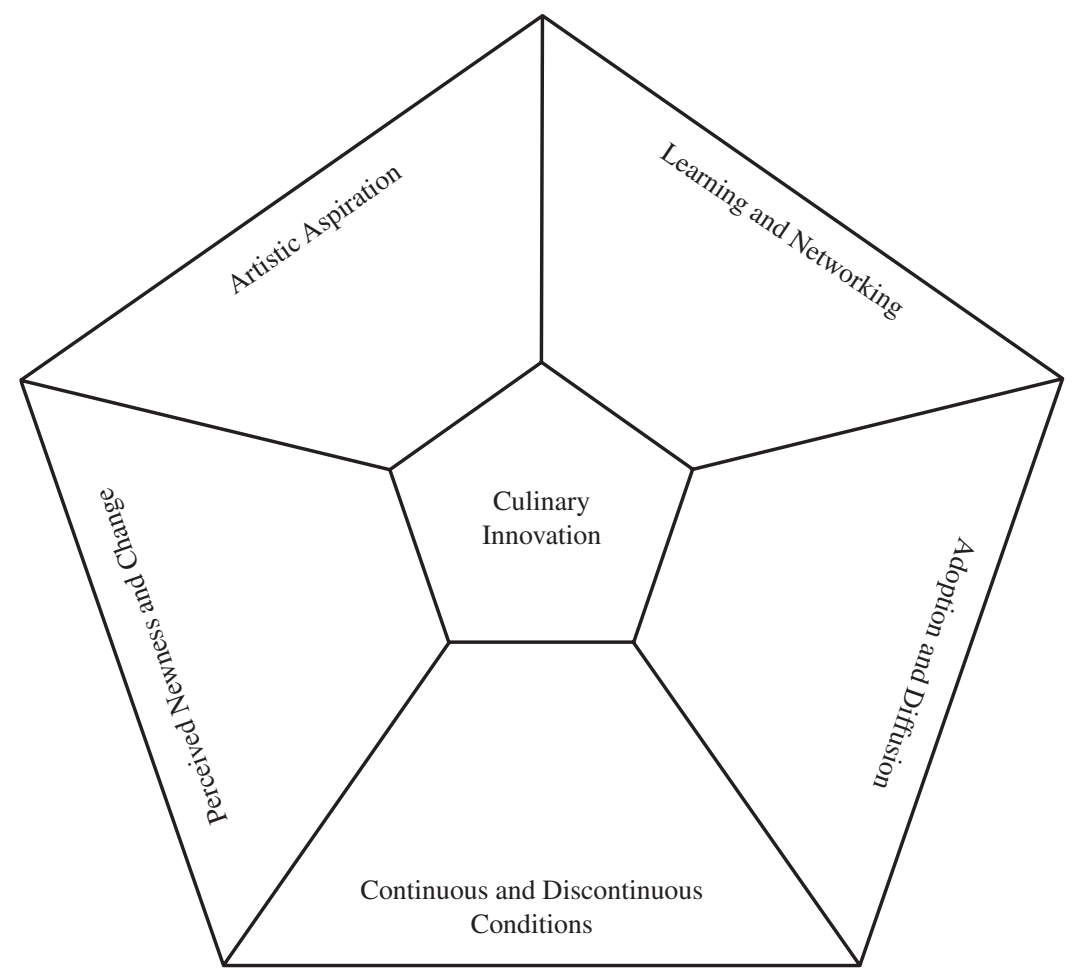

Figure 1 Potential dimensions of culinary innovation

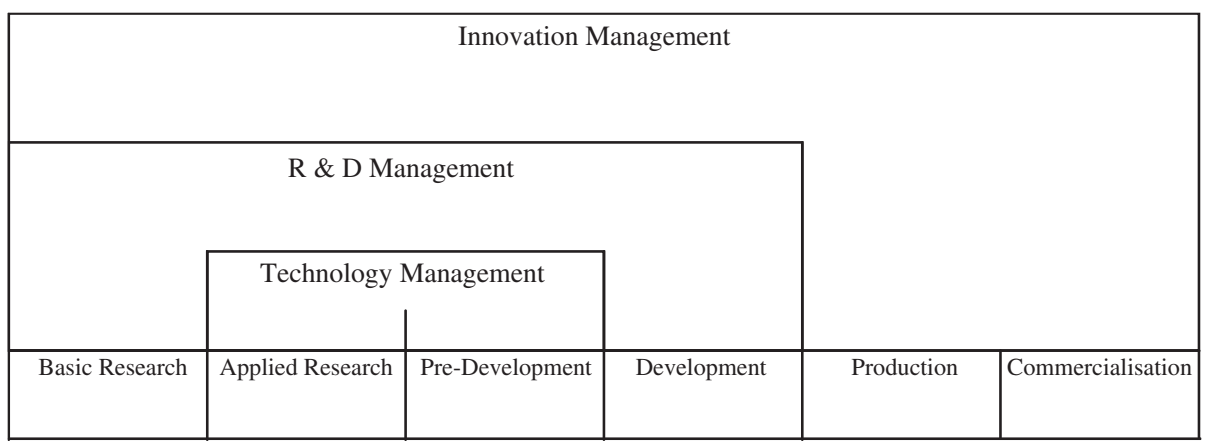

Figure 2 Scope of innovation management After Vahs and Burmester (2002)

As a consequence, inventions are understood in this study as developed and mostly technical problem solutions that can be either planned or serendipitous (Borchert et al., 2004). Innovations, on the other hand, are seen as a heuristic process entailing new idea creation and, in case of the success of the innovation, the creation of a new value (cf. Csíkszentmihályi, 1997; Baracskai et al., 2007). This interpretation of culinary innovation is considered to be appropriate in light of its aforementioned interpersonal dimension that implies differences in the interpretation of value (see Schumpeter, 1911/1934), but entails that successful culinary innovations are adopted and diffused on grounds of their recognised meaning and value within the social system (cf. Polányi, 1962a on the concept of meaning). 


\section{Artistic aspirations}

It became clear that academia is uncertain about the nature of elite chefs, but rather quick to dismiss the idea of Haute Cuisine as AvantGarde, Cultural Expression, or even something artistic as this might be considered polemic and presumptuous (Ferran Adria in WeberLamberdière, 2007). Why can elite chefs, however, not be compared with other artists? To the contrary, academia should reconsider the artistic role of elite chefs, especially by means of theories of the humanities. None of the studies that explicitly mention culinary innovation try to explore the life worlds of elite chefs, who live between the often-restricted palate and the limited appetite for culinary discoveries of their paying customers as well as their own artistic aspirations. This problem is clearly difficult for young elite chefs, who yet have to proof their distinctive culinary style, while senior elite chefs seem to better cope with this strain, because they already left their traces in culinary history (cf. Leschziner, 2007; Stierand and Sandt, 2007).

Creative tensions, however, are also created within the field. Haute Cuisine involves normative, regulative, and cultural-cognitive dimensions, which form the identity of elite chefs and establishes symbols, routines, and artefacts that are justified by the logics of the empirical world of gastronomy and its interpersonal relationships (cf. Scott, 2001). These dimensions influence which culinary innovations will be adopted and diffused and therefore directly impact the freedom of creativity and artistic aspiration of elite chefs. New culinary ideas are thus embedded in both conformity and consensus and in conflict and change (cf. Scott, 2004). Though, by reading the only two studies that explicitly focus on culinary innovation - that is Harrington (2004a,b) and Ottenbacher and Harrington (2007) - there are no signs of questions and inspirational interpretations that intend to show what the broader empirical world of gastronomic institutionalism looks like and what influences it has on elite chefs and their culinary creations. The study of
Ottenbacher and Harrington (2007), in particular, implies the feeling of misunderstanding between academia and chefs and it appears that the voices of chefs are conveniently interpreted to serve the strategic purpose of creating commercialisable knowledge for the industry. To provide evidence for this claim, Ottenbacher and Harrington state that "with respect to innovative new dishes the differentiator is not the product itself but rather the quality of the product' (Ottenbacher and Harrington, 2007). This truism, however, is a rather banal starting point for a discussion about culinary innovation of elite chefs and allows two conclusions to be made. First, the questions asked by Ottenbacher and Harrington were unclear to the chefs, who then answered too broadly without explaining what they understand by culinary innovation. Secondly, the researchers lacked the skills to challenge these chefs and dig deeper into their worlds.

The need to dig deeper into the world of elite chefs can be demonstrated by the example of Gordon Ramsay who describes his reality as a young chef in Paris. After he had already served under the patronage of Guy Savoy, where 'even the kitchen porters had...no respect for [him]...[and] [n]o one was interested that [he would] come from a three-star restaurant' (Ramsay, 2006), he went to Joël Robuchon from where he reports the following:

'So I went to the great Joël Robuchon where - guess what? - I had to start from the beginning all over again. Yes, believe it or not, I went straight back to being a humble commis. Again. And this time the humiliation was on a whole new level. Robuchon was the most famous restaurant in the world at the time. It had just forty-five seats, and was as snooty as they come - and I'm talking about the way they treated us, not the customers. When you arrived at the restaurant, you had to ring a bell and then stand there while one of the waiting staff let you in. You had a key, but you weren't allowed to 
use it. Robuchon himself had a lavatory that only he and his wife were allowed to use. The kitchen was in a kind of corridor. Once you were installed there, you simple didn't move for the next five hours, and it was like the fucking SAS. Robuchon made Marco [Pierre White] look like a fucking pussy cat. It was extraordinary'. (Ramsay, 2006)

This narrative shows that if culinary research does not understand the sociology of elite chefs it cannot understand how culinary innovation is perceived, negotiated, adopted, diffused, and inherited (cf. Berger and Luckmann, 1966; Knorr-Cetina, 1981; Lincoln and Guba, 1985) and what the nature of learning and networking is in the world of institutional gastronomy under continuous and discontinuous conditions.

\section{Continuous and discontinuous conditions}

Current perspectives on culinary innovation seem to be overly technical and partly grounded in the 1950s when innovation was understood as simply covering product and process technologies that are developed in a naïvely steady world. At this time, management theorists believed innovation to be a linear process consisting of steps like research and development, market launch (Lederer, 1989), and adoption (Rogers, 1983 quoted in Hauschildt, 1997). This 'technology-push approach' (cf. Rothwell, 1992, 1994) assumed that market needs could be easily identified (Kameoka et al., 2001) and firms could linearly respond with their innovative products that were based on existing technologies (cf. Perunovic and Christiansen, 2005; Tidd et al., 2005). Since reality showed that this was a fatally narrow view, a 'need-pull approach' emerged in the mid-1960s that focused on the consumer as the true barometer for the linear production of innovation (cf. Rothwell, 1992, 1994; Tidd et al., 2005). While this approach was too limited as well, both approaches were combined in the mid-1970s into a 'coupling approach' that included a feed- back loop to control likely discontinuities between firm and consumer.

The current culinary innovation studies also assume this naïvely steady world and apply mainly epistemologies that remain in the 1970s. This limited view, however, creates the illusion that culinary innovation is a well-structured problem, presuming that there are exact criteria to test solutions and to blueprint each single phase of the culinary innovation process (see Simon, 1973 on well-structured problems). What these studies, however, actually achieve is an artificially validated process under a condition that Bessant and Caffyn (1997) termed as continuous innovation. Under this condition, innovation is nothing more than a process of improvement that takes place in a framework of existing and known rules. Simply said, continuous innovation means to do things as usual but better. This does not exclude significant changes but implies that changes occur within an established framework.

The 1980s, however, showed a first attempt to accept that innovation is embedded in a complex world of networks and interpersonal relationships. This 'integrated approach' was further pursued and the emerging pressures of globalisation in the 1990s made it even more evident that innovation is a seismograph of time and space. This last generation of innovation, which Rothwell calls the "fifth mode of innovation', changed the social construction of innovation approaches by also considering the disorganisation of organisation as part of the phenomenon (eg Castells, 2000; Lash and Urry, 1987). Figure 3 illustrates these aforementioned innovation approaches.

Certainly, continuous innovation is already complex, because of its personal and local character, but future studies cannot ignore culinary innovations that are influenced by discontinuous and chaotic conditions just because it increases the complexity of the concept. Schumpeter's image of innovations as waves of creative destruction still prevails as a major discussion among leading scholars from diverse disciplines (see Malerba, 2006). In essence, 


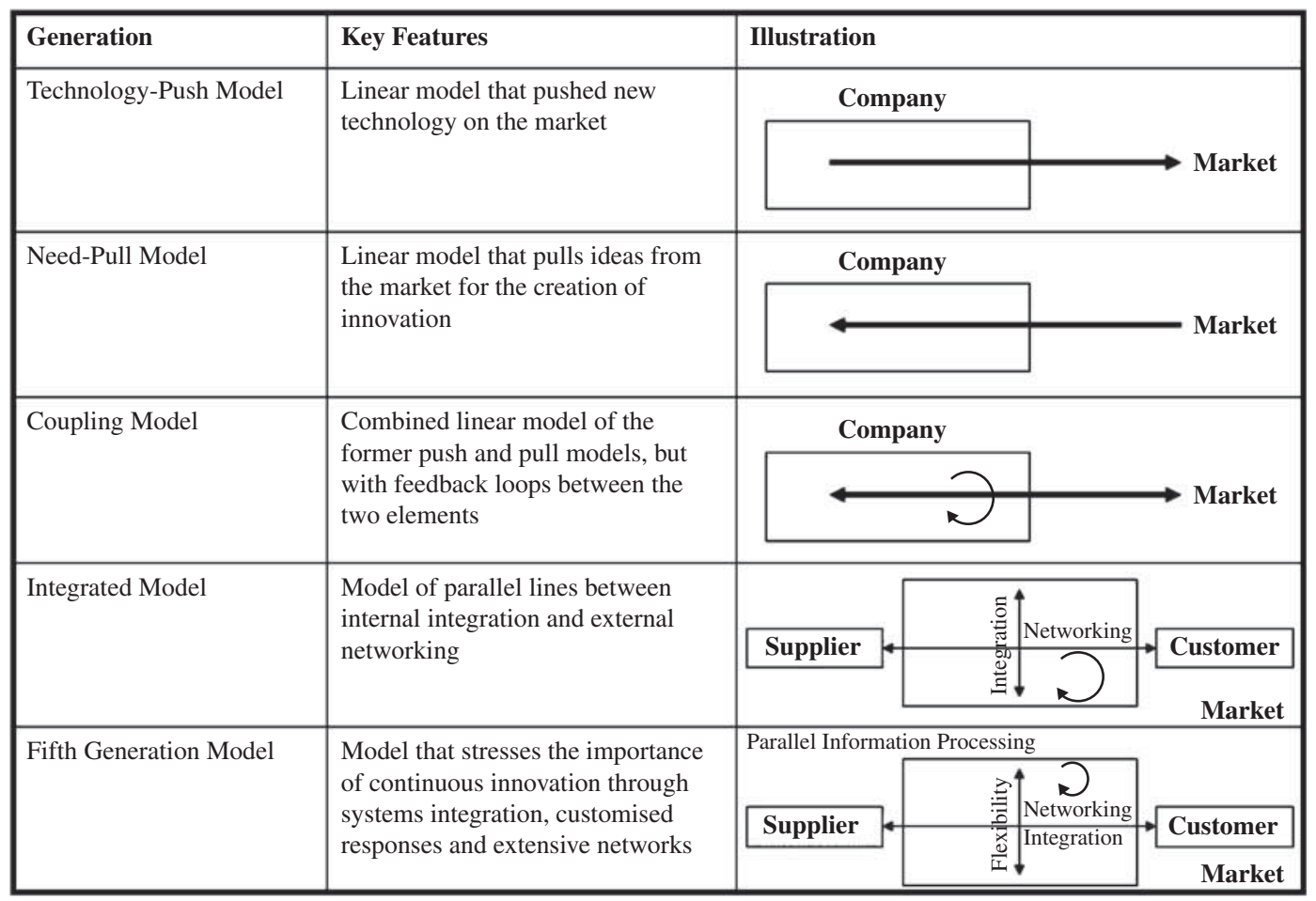

Figure 3 Rothwell's five generations of innovation approaches Own figure adapted from Perunovic and Christiansen (2005)

Schumpeter challenged the status quo of capitalism by saying that the crux of capitalism is not how to manage existing structures, but how to destroy them and create new ones, favouring those firms that react fast enough and are able to take hold of discontinuities. Schumpeter was an economist, but his idea of creative destruction can provide the ground for many personal dimensions and should be a notion of general interest to all innovation researchers. This discussion, however, seems to be widely ignored in the studies of Harrington and Ottenbacher.

Discontinuity can be a scary notion, because it is not an everyday event that forces innovators to experiment in order to accumulate new knowledge that can help them to keep track in an unpredictable world. During times of experimentation, a so-called dominant design emerges that in some way predicts the most popular but not necessarily the most sophisti- cated trajectory of the future. The old trajectories, however, are still in place and normally undergo rapid improvements, which in turn sharpen the conditions for all actors (Tidd, 2006). Clayton Christensen (1997), for example, impressively portrays how the appearance of new markets can create different needs and expectations and hence establish discontinuous conditions. These new markets can disrupt existing innovators even if they have supposedly perfected their innovation machinery, but have just missed to recognise the power of the adjoining slowly growing market (Tidd, 2006) that starts rebelling against existing rules and demands new performance features or refuses to consume and thus demands the creation of an entirely new trajectory (Christensen and Raynor, 2003).

The world of culinary innovation in current studies pretends to be just a well-structured problem under continuous conditions. Therefore, 
the contribution of these studies should be considered as task fulfilment rather than as problem-solving, because the ill-structured problem under discontinuous conditions is neglected (cf. Baracskai, 1997; Dörfler, 2005). As a result, future research should try to focus on how to structure the problem of innovation so that the ill-structured problem of culinary innovation can perhaps become a wellstructured task in future (cf. Eden, 1987).

\section{Learning and networking}

These conditions discussed above are believed to affect the learning and knowledge of elite chefs. The knowledge of individual elite chefs is affected by the social system as described by Polányi in his concept of tradition (cf. Polányi, 1962a). He refers to tradition as a system of values that influences the transfer of knowledge within a social milieu. Such 'communities of practice' (Jacobs, 2002; Polányi, 1962a focused on communities of scientific practice) influence innovation and are therefore additional evidence that the phenomenon of culinary innovation is not an isolated event but is interlinked with its social environment (cf. Castells, 2000). Morrison et al. (2004), for example, introduce the term 'learning communities' to describe institutional networks that have a common purpose and provide their members with cohesion and benefits that are summarised by Lynch et al. (2000) as being learning and exchange, common business activity, and community building. These networks can be of formal, semi-formal, or even informal character (Gibson et al., 2005), but it is their underlying logic that is of importance to help inducing innovation by structuring the unstructured (or ill-structured), but also by providing flexibility to the unstructured that is believed to be the engine of innovative human action (Castells, 2000).

Referring to the aforementioned view of innovation as a heuristic process of idea creation and value creation can now help us to see the relevance of knowledge and networking. Idea creation is the creative process in which ill-structured problems are tried to be solved (Simon, 1973) by rearranging one's existing knowledge (Dörfler, 2004). If an elite chef decides on a new culinary idea, it is the network of gatekeepers that will decide on the validity of the idea (Csíkszentmihályi, 1997). This mechanism can be related to Polanyi's (Polányi, 1966) 'principle of mutual control', or Popper's (2004) 'inter-subjective testing', and shows how influential networks are for the journey of 'pitching the brilliant idea' into a valuable innovation. The new culinary value, in turn, is validated through the co-creation of catchers who promote the new value (Elsbach, 2003). Culinary innovation is therefore described in this study as personal culinary innovation and interpreted as 'material or symbolic artefact, which [elite chefs] perceive as novel and as an improvement in comparison to the existing' (paraphrasing Braun-Thürmann, 2005).

Both Polányi (1962b) and Heisenberg (2000) state that the attribute 'personal' symbolises that knowledge depends on the knower's personal characteristics like mood, attitude, emotions, and value system so Ottenbacher and Gnoth's (2005) assessment, that 'the major benefit of successful innovation is to be or become more competitive', becomes a naïvely narrow view of the phenomenon. These two authors mention, for example, the visiting of a colleague's restaurant, travelling abroad, experiences from previous employers, or ideas from customers as sources of inspiration for chefs, but they do not further elaborate on these aspects with the lens of networking and learning or other theories that could strengthen their arguments.

\section{Adoption and diffusion}

The discourse so far has shown that culinary innovation is a balancing act between the sophistication and the popularity of the new idea, but the current studies fail to discuss this important issue. The theory of adoption and diffusion explains the acceptance and use of an innovation (see Stockmeyer, 2002) that depends on the individual perception (see 
Bähr-Seppelfricke, 1999) of how rule-breaking but also of how compatible the innovation is with values, needs, and past experiences (see Rogers, 1983; Rogers and Shoemaker, 1971). The social system is again an important aspect to consider, because social systems generally tend to avoid innovation while in fact they are in need of it (see Sauer and Lang, 1999; Weick, 1985). Social systems are selective in order to secure the system (Pohlmann, 2005) and therefore members of the system argue that their innovations cannot be too contrary to the system's sense-making culture (Peter, 1970). This argument is also confirmed by one of Ottenbacher and Harrington's interviewed chefs:

'I can't be too trendy because my customers have a conservative taste; therefore, I always use a conservative filter before advancing with the new idea'. (Ottenbacher and Harrington, 2007)

Ottenbacher and Harrington, however, again did not further elaborate on the above statement so that this paper wants to provide their missing interpretation by arguing that the voice of the above chef shows that the resistance to change tends to grow when the stability of rationalised fiction between power and trust is disturbed (Meyer and Rowan, 1977). Ottenbacher and Harrington indeed fulfilled the task to mention that some of their chefs undertake a customer-oriented screening of their innovations, but they do not use the theories of adoption and diffusion to help in solving the problem of culinary innovation.

As a result and to contribute to the progress of the culinary research agenda, this study proposes that future research has to explore how complementary and complex culinary innovations can be in order to be accepted by the social system (see Fliegel and Kivlin, 1966). For example, it is as important that innovations are understood by the members of the social system (Agarwal and Prasad, 1997) as it is important that elite chefs understand academics and vice versa. This mutual understanding helps to limit the perceived risk (Meyer and Goes, 1988; Meyer et al., 1997) and uncertainty (Wolfe, 1994) that can emerge in the shape of financial costs (Zaltman et al., 1973) and social costs that have effects on status (Wolfe, 1994), power, interpersonal relationships (Zaltman et al., 1973), and image (Agarwal and Prasad, 1997). Time is another indicator that shows that after a certain point in time, an adoption may not be seen as rewarding (Zaltman et al., 1973) so that time is not only an indicator of how fast an innovation gets adopted and diffused but also of how well the new and its change to the existing is perceived.

\section{Perceived newness and change}

The concept of perceived newness and change is mentioned in several major studies and is sometimes called the degree of innovativeness (eg Cheng and Van de Ven, 1996; Damanpour, 1991; Garcia and Calantone, 2002; Kleinschmidt and Cooper, 1991; Veryzer, 1998). Perceived newness and change is related to the notion of adoption and diffusion, because it is relevant who considers an innovation as new (Johannessen et al., 2001). The literature, however, mainly explains this problem in a commercial context. Some scholars argue, for example, that newness can be considered in relation to the firm or market (Cooper, 1993; Kotabe and Swan, 1995). This firm-based framework can thus be interpreted as describing internal innovations that are unlikely to have direct impacts on the external social system, but help to maintain the innovativeness of the individual and may affect how the individual is perceived by the outside world. The more broadly created notion of 'relevant units of adoption', as introduced by Zaltman et al. (1973), however, relates to the personal character of innovations by establishing a continuum of relevant units of adoption.

Newness is therefore context-specific and is evaluated along continua that describe the quality of newness (see Avlonitis et al., 2001; Daneels and Kleinschmidt, 2001; LeonardBarton, 1998). This quality, magnitude, or 
pervasiveness of change describes - in rather technical metaphors - how innovation displaces existing states and is individually perceived by comparing the magnitude of change with other changes (see West and Anderson, 1996). Metaphoric terms like incremental and radical describe innovations that entail a low degree of change from existing practices (Damanpour, 1996) and innovations that entail fundamental changes that can be seen as new paradigm (Lambe and Spekman, 1997). Similar descriptions are given by the terms evolutionary and revolutionary innovations (Rabson and DeMarco, 1999), individual and synergistic innovations (Goodman, 1981), and instrumental and ultimate innovations (Wolfe, 1994).

These terminological games, however, create only more confusion with the consequence that the incremental and radical dichotomy is often confused with the concept of continuous and discontinuous innovations mentioned earlier. As a result, this study favours the idea of Henderson and Clark (1990), who stress that a distinction along the incremental-radical dichotomy is not sufficient enough to explain how individuals distinguish between their perceptions of newness and change and therefore propose to explain the notion of perceived newness by knowledge levels. They identified distinct levels of knowledge of both innovator and adopter that influence the creation, adoption, and diffusion of innovation. Knowledge that is only sufficient to understand components of what might be called a 'full innovation' can only create incremental innovations that show improved components, but show no change in their dominant architecture (ie structure or design). Knowledge to create radical innovations, in contrast, must be deeply routed in the understanding of both components and architecture. Henderson and Clark (1990) further distinguish between modular innovations that require extensive component knowledge, but lesser architectural knowledge, because they significantly change the components while leaving the dominant architecture untouched,

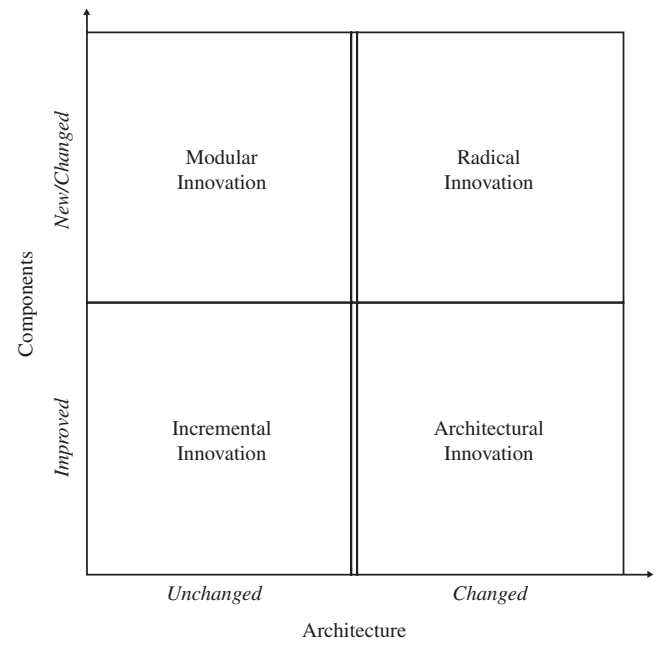

Figure 4 Henderson and Clark model (1990)

and architectural innovation that requires deep architectural knowledge, but only little component knowledge as it fundamentally changes the dominant architecture. Figure 4 illustrates the ideas of Henderson and Clark's approach.

In conclusion, the construct of perceived newness and change also entails the aforementioned aspect of objects of innovation that Harrington limits to goods and services only. The aspect of innovation objects, however, draws a relationship to the earlier discussed dichotomies of instrumental-ultimate and individual-synergistic innovations by highlighting the relevance of autonomy, which means that some innovations can be created, adopted, and diffused independently from other innovations; whereas others require additional innovations to be created or adapted in order to be effective (Chesborough and Teece, 1996).

\section{CONCLUSION AND RECOMMENDATIONS}

The uncovering of everyday actions and interactions of chefs is identified as important in achieving a better understanding of culinary innovation. It is recommended that future studies explore the perceptions, beliefs, explanations, and views of innovating chefs and 
analyse the consequences these chefs face for their innovating behaviours and for those with whom they interact. In order to identify which chefs are considered as innovators, this study proposes the concept of personal culinary innovation, because it is valid and verifiable through its commitment to a reality that is external to the chef and that is controlled by gatekeepers who decide whether or not chefs are recognised as innovators. Networks and culinary tradition are therefore seen as significant influences of how knowledge is transferred within the social milieu of elite chefs.

Furthermore, this paper intended to stimulate the academy to reconsider the artistic role of elite chefs, which can change the directions of how culinary innovation may be approached in future. Consequently, it is shown that researchers should increase their knowledge of the sociology of chefs and that it is essential to recognise the different philosophies of cuisine so as to build a mutual dialogue. This dialogue is believed to represent the key to a better understanding of how culinary innovation is perceived, negotiated, adopted, diffused, and inherited in the world of institutional gastronomy. The lack of such a dialogue, however, has created studies that interchangeably and wrongly use the term invention and innovation and fail to address central dimensions such as artistic aspiration, continuous and discontinuous conditions, learning and networking, adoption and diffusion as well as perceived newness and change.

In conclusion, it is the successful explanation of how to structure the problem of culinary innovation that is believed to progress the understanding of the phenomenon and might be an essential part of solving the problem.

\section{References}

Adria, F., Blumenthal, H., Keller, T. and McGee, H. (2006) 'Statement on the "New Cookery", The Observer, London.

Agarwal, R. and Prasad, J. (1997) 'The Role of Innovation Characteristics and Perceived Voluntariness in the Acceptance of Information
Technologies', Decision Sciences, 28, 3, 557-582.

Avlonitis, G., Papastathopoulou, P. and Gounaris, S. (2001) 'An Empirically-Based Typology of Product Innovativeness for New Financial Services: Success and failure scenarios', Journal of Product Innovation Management, 18, 5, 324-342.

Bähr-Seppelfricke, U. (1999) 'Diffusion neuer Produkte: der Einfluss von Produkteigenschaften', Wiesbaden, Deutscher UniversitätsVerlag.

Baracskai, Z. (1997) 'Profi döntések (Master of Decision Taking) — Szabolcs-Szatmár-Bereg megyei Könyvtárak', Nyíregyháza, Hungary, Egyesülés.

Baracskai, Z., Dörfler, V. and Velencei, J. (2007) 'Knowledge Restaurants at the End of the Paradigm. Symposia on internet related research with elements of $\mathrm{M}+\mathrm{I}+\mathrm{T}++$ ', VIPSI, Tokyo.

Berger, P. and Luckmann, T. (1966) 'The Social Construction of Reality: A treatise in the sociology of knowledge', Anchor Books, Garden City, NY.

Bessant, J. and Caffyn, S. (1997) 'High-Involvement Innovation through Continuous Improvement', International Journal of Technology Management, 14, 1, 7-28.

Borchert, J., Goos, P. and Hagenhoff, S. (2004) 'Innovations- und Technologiemanagement: Eine Bestandsaufnahme', in Schumann, M. (ed), 'Arbeitsbericht 4/2003', Institut für Wirtschaftsinformatik, Georg-August-Universität, Göttingen.

Bourdieu, P. (1984) 'Distinction: A social critique of the judgement of taste', Routledge, London.

Braun-Thürmann, H. (2005) 'Innovation', TranscriptVerlag, Bielefeld.

Castells, M. (2000) 'The Rise of the Network Society', Blackwell, Malden, MA.

Cheng, Y. -T. and Van de Ven, A. (1996) 'Learning the Innovation Journey: Order out of chaos?' Organization Science, 7, 6, 593-614.

Chesborough, H. and Teece, D. (1996) 'When is Virtual Virtuous? Organizing for Innovation', Harvard Business Review, 74, 1, 65-73.

Christensen, C. (1997) 'The Innovator's Dilemma', Harvard Business School Press, Cambridge, A.

Christensen, C. and Raynor, M. (2003) 'The Innovator's Solution: Creating and sustaining 
succesful growth', Harvard Business School Press, Cambridge, MA.

Cooper, R. (1993) 'Winning at New Products: Accelerating the process from idea to launch', 2nd edn, Addison-Wesley, Reading, MA.

Csíkszentmihályi, M. (1997) 'Creativity: Flow and the psychology of discovery and invention', HarperCollins, New York, NY.

Damanpour, F. (1991) 'Organizational Innovation: A meta-analysis of effects of determinants and moderators', Academy of Management Journal, 34, 555-591.

Damanpour, F. (1996) 'Organizational Complexity and Innovation: Developing and testing multiple contingency models', Management Science, 42, 5, 693-719.

Daneels, E. and Kleinschmidt, E. (2001) 'Product Innovativeness from the Firm's Perspective: Its dimensions and their relation with project selection and performance', Journal of Product Innovation Management, 18, 6, 357-373.

Dörfler, V. (2004) 'Descriptive Model of Learning Capability', in Third Annual Conference on Information Science Technology and Management, Alexandria, Egypt.

Dörfler, V. (2005) 'Model of Learning Ability', Department of Management Science, University of Strathclyde, Glasgow.

Drucker, P. (2006) 'Innovation and Entrepreneurship: Practice and principles', Elsevier Butterworth Heinemann, Oxford.

Durand, R., Rao, H. and Monin, P. (2007) 'Code and Conduct in French Cuisine: Impact of code changes on external evaluations', Strategic Management Journal, 28, 455-472.

Eden, C. (1987) 'Problem Solving or Problem Finishing?', in Jackson, M. and Keys, P. (eds), 'New Directions in Management Science', Gower, Hants.

Elsbach, K. (2003) 'How to Pitch a Brilliant Idea', Harvard Business Review, 81, 1-7.

Escoffier, A. (1993) 'A Guide to Modern Cookery', Heinemann, London.

Ferguson, P. (2004) 'Accounting for Taste: The triumph of French cuisine', University of Chicago Press, Chicago, IL.

Fliegel, F. and Kivlin, J. (1966) 'Attributes of Innovations as Factors in Diffusion', American Journal of Sociology, 72, 3, 235-248.
Ganter, H. -D. (2004) 'Changes in Work Organisation in French Top-Quality Restaurants', Business History Review, 46, 3, 429-460.

Garcia, R. and Calantone, R. (2002) 'A Critical Look at Technological Innovation Typology and Innovativeness Terminology: A literature review', Journal of Product Innovation Management, 19, 2, 110-132.

Gibson, L., Lynch, P. and Morrison, A. (2005) 'The Local Destination Tourism Network', Tourism and Hospitality Planning and Development, 2, 2, 87-99.

Goldberg, P. (1985) 'The Intuitive Edge: Understanding and developing intuition', Turnstone Press, Wellingborough.

Goodman, R. (1981) 'Temporary Systems: Professional development, manpower, utilization, task-effectiveness, and innovation', Praeger Publishers, New York.

Harrington, R. (2004a) 'Part I: The Culinary Innovation Process - A barrier to imitation', Journal of Foodservice Business Research, 7, 3, 35-57.

Harrington, R. (2004b) 'Part II: Rice Flour Beignets - A case study of the culinary innovation process', Journal of Foodservice Business Research, 7, 3, 59-72.

Hauschildt, J. (1997) 'Innovations Management', Vahten, München.

Heidegger, M. (1962/1927) 'Being and Time', Harper, New York.

Heisenberg, W. (2000) 'Physics and Philosophy: The revolution in modern science', Penguin Books, London.

Henderson, R. and Clark, K. (1990) 'Architectural Innovation: The reconfiguration of existing product technologies and the failure of established firms', Administrative Science Quarterly, 35, 9-31.

Hofer, S. and Kamolz, K. (2007) 'Ein nacktes Huhn ist nicht sehr schön', in Profil — Das unabhängige Nachrichtenmagazin Österreichs.

Husserl, E. (1970/1936) 'Crisis of European Sciences and Transcendental Phenomenology', Northwestern University Press, Evanston, IL.

Jacobs, S. (2002) 'Polanyi's Presagement of the Incommensurability Concept', Studies in History and Philosophy of Science, 33, 105-120.

Johannessen, J.-A., Olsen, B. and Lumpkin, G. (2001) 'Innovation as Newness: What is new, how 
new, and new to whom?' European Journal of Innovation Management, 4, 1, 20-31.

Kameoka, A., Ito, H. and Kobayashi, K. (2001) 'A cross-generation framework for deriving next generation innovation process model', in IEMC (ed), 'Change Management and the New Industrial Revolution', IEMC, Albany, New York.

Kleinschmidt, E. and Cooper, R. (1991) 'The Impact of Product Innovativeness on Performance', Journal of Product Innovation Management, 8, 4, 240-251.

Knorr-Cetina, K. (1981) 'The Manufacture of Knowledge: An essay on the constructivists and contextual nature of science', Pergamon, Oxford.

Kotabe, M. and Swan, K. (1995) 'The Role of Strategic Alliances in High Technology New Product Development', Strategic Management Journal, 16, 8, 621-636.

Lambe, C. and Spekman, R. (1997) 'Alliances, External Technology Acquisition, and Discontinuous Technological Change', Journal of Product Innovation Management, 14, 2, 102-116.

Lash, S. and Urry, J. (1987) 'The End of Organized Capitalism', Polity, Cambridge.

Lederer, M. (1989) 'Innovations management', in $\mathrm{ZfB}$ - Zeitschrift fuer Betriebswirtschaft.

Leonard-Barton, D. (1998) 'Wellsprings of Knowledge: Building and sustaining the sources of innovation', Harvard Business School Press, Boston, MA.

Leschziner, V. (2007) 'Kitchen Stories: Patterns of recognition in contemporary high cuisine', Sociological Forum, 22, 1, 77-101.

Lincoln,Y. and Guba,Y. (1985) 'Naturalistic Inquiry', Sage, Beverly Hills, CA.

Lynch, P., Halcro, K., Johns, N. and Buick, I. (2000) 'Developing Small Business Networks to Build Profitable Tourist Destinations. Destination Development Conference', Mid Sweden University, Osterlund, Sweden.

Malerba, F. (2006) 'Innovation and the Evolution of Industries', Journal of Evolutionary Economics, 16, 3-23.

Merleau-Ponty, M. (1962/1945) 'Phenomenology of Perception', Routledge \& Kegan Paul, London.

Meyer, A. and Goes, J. (1988) 'Organizational Assimilation of Innovations: A multilevel contextual analysis', Academy of Management Journal, 31, 4, 897-923.
Meyer, J. and Rowan, B. (1977) 'Institutionalized Organizations: Formal structure as myth and ceremony', American Journal of Sociology, 83, 2, 340-363.

Meyer, M., Johnson, J. and Ethington, C. (1997) 'Contrasting Attributes of Preventive Health Innovations', Journal of Communication, 47, 2, $112-131$.

Mill, J. (2002) 'A System of Logic: Ratiocinative and inductive', University Press of the Pacific, Honolulu.

Monin, P. (2005) 'Building with, or on the Ruins? Institutional Change in the French Haute Cuisine Field (1951-2000) as Transformations in Symbolic Systems, Organizational Routines and Artefacts', E.M. Lyon, Lyon.

Morrison, A., Lynch, P. and Johns, N. (2004) 'International Tourism Networks', International Journal of Contemporary Hospitality Management, 16, 3, 198-204.

Ottenbacher, M. and Gnoth, J. (2005) 'How to Develop Successful Hospitality Innovation', Cornell Hotel and Restaurant Administration Quarterly, 46, 2, 205-222.

Ottenbacher, M. and Harrington, R. (2007) 'The Innovation Development Process of Michelin-Starred Chefs', International Journal of Contemporary Hospitality Management, 19, 6, 444-460.

Perunovic, Z. and Christiansen, T. (2005) 'Exploring Danish Innovative Manufacturing Performance', Technovation, 25, 9, 1051-1058.

Peter, L. (1970) 'Das Peter-Prinzip oder Die Hierarchie der Unfähigen', Rowohlt, Reinbek bei Hamburg.

Peterson, R. and Kern, R. (1996) 'Changing Highbrow Taste: From snob to omnivore', American Sociological Review, 61, 900-907.

Pohlmann, M. (2005) 'The Evolution of Innovation: Cultural backgrounds and the use of innovation models', Technology Analysis \& Strategic Management, 17, 1, 9-19.

Polányi,M.(1962a) 'Personal Knowledge', Routledge and Kegan Paul, London.

Polányi, M. (1962b) 'The Republic of Science: Its political and economic theory', Minerva, 1, 54-74.

Polányi, M. (1966) 'Science, Faith and Society', The University of Chicago Press, Chicago, IL.

Popper, K. (2004) 'The Logic of Scientific Discovery', Routledge, London. 
Rabson, J. and DeMarco, D. (1999) 'A Model of Innovation Systems with Links to Creative Style and Psychological Type', International Journal of Technology Management, 18, 5-8, 627-647.

Ramsay, G. (2006) 'Humble Pie - My autobiography’, HarperCollins, London.

Rao, H., Monin, P. and Durand, R. (2003) 'Institutional Change in Toque Ville: Nouvelle cuisine as an identity movement in French gastronomy', American Journal of Sociology, 108, 4, 795-843.

Rao, H., Monin, P. and Durand, R. (2005) 'Border Crossing: Bricolage and the erosion of categorical boundaries in French gastronomy', American Sociological Review, 70, 6, 968-991.

Rehn, A. (2006) 'Anachronism and Innovation: A case of hybrid economies in the early 19th century', Management \& Organizational History, 1, 1, 71-86.

Rogers, E. (1983) 'Diffusion of Innovations', 3rd edn, Free Press, New York.

Rogers, E. and Shoemaker, F. (1971) 'Communication and Innovations: A cross-cultural approach', 2nd edn, Free Press, New York/London.

Rogers, S. (2008) 'Technological Innovation Supporting Different Food Production Philosophies in the Food Service Sectors', International Journal of Contemporary Hospitality Management, 20, 1, 19-34

Rothwell, R. (1992) 'Successful Industrial Innovation: Critical factors for the 1990's', RED Management, 22, 3, 221-239.

Rothwell, R. (1994) 'Towards the Fifth-Generation Innovation Process', International Marketing Review, 11, 1, 7-31.

Sauer, D. and Lang, C., (eds) (1999) 'Paradoxien der Innovation. Perspektiven Sozialwissenschaftlicher Innovationsforschung', Campus, Frankfurt am Main.

Schopenhauer, A. (1851) 'Parerga and Paralipomena', Six Long Philosophical Essays, Oxford University Press, Oxford.

Schumpeter, J. (1911/1934) 'The Theory of Economic Development', Harvard University Press, Cambridge.
Scott, W. (2001) 'Institutions and Organisations', San Francisco, Sage.

Scott, W. (2004) 'Institutional Theory', in Ritzer, G. (ed), 'Encyclopedia of Social Theory', Thousand Oaks, CA, Sage.

Simon, H. (1973) 'The Structure of Ill Structured Problems', Artificial Intelligence, 4, 3-4, 181-201.

Stierand, M. and Sandt, J. (2007) 'Organising HauteCuisine Service Processes: A case study', Journal of Hospitality and Tourism Management, 14, 1, 24-36.

Stockmeyer, B. (2002) 'Ansatzpunkte und Methoden zur Effizienzsteigerung im Innovationsmanagement der Ernährungsindustrie', Herbert Utz, München.

Tidd, J. (2006) 'A Review of Innovation Models', Discussion paper, Imperial College, London.

Tidd, J., Bessant, J. and Pavitt, K. (2005) 'Managing Innovation: Integrating technological, market and organizational change', 3rd edn, John Wiley \& Sons, Chichester.

Vahs, D. and Burmester, R. (2002) 'Innovationsmanagement: von der Produktidee zur erfolgreichen Vermarktung', Stuttgart Schäffer/Poeschel.

Veryzer, R. (1998) 'Discontinuous Innovation and the New Product Development Process', Journal of Product Innovation Management, 15, 4, 304-321.

Weber-Lamberdière, M. (2007) 'Die Revolutionen des Ferran Adrià — Wie ein Katalane das Kochen zur Kunst machte', Bloomsbury Berlin, Berlin.

Weick, K. (1985) 'Der Prozeß des Organisierens', Suhrkamp, Frankfurt am Main.

West, M. and Anderson, N. (1996) 'Innovation in Top Management Teams', Journal of Applied Psychology, 81, 6, 680-693.

Wolfe, R. (1994) 'Organizational Innovation: Review, critique and suggested research directions', Journal of Management Studies, 31, 3, 405-431.

Zaltman, G., Duncan, R. and Holbek, J. (1973) 'Innovations and Organisations', John Wiley \& Sons, New York. 